\title{
Another Side of North Korea: Business for Profit
}

\author{
Sang T. Choe \\ University of Southern Indiana \\ Timothy B. Mahoney \\ University of Southern Indiana
}

As one of the remaining five communist countries on earth, North Korea became infamous in recent years with its nuclear issues with the outside world and political instability inside the country. This paper, looks at North Korea from a different angle to identify its strengths and potentials in the future to become a productive global citizen by identifying five key factors; (1) untapped underground resources, (2) economic geography favorable for effective supply chain via land routes, (3) affordable labor force with discipline and education, (4) people's desire to achieve economic wellbeing, and (5) latent needs of variety of consumer goods.

\section{INTRODUCTION}

In recent years, few days pass without our being exposed to negative news regarding North Korea, one of the last five remaining communist countries (Cote 2013). News coverage of North Korea mainly revolves around two categories: nuclear missile development, and the detention of visiting American citizens. The North Korea nuclear missile program began in the early 1980s as a deterrent from foreign aggressors. North Korea has developed their program by conducting long-range missile tests, which has become a 'hot topic' for media outlets, and contributes to mounting tensions with foreign nations. Media outlets have also focused on the detention of American citizens in North Korea over the last few years, specifically from year 2010 to 2016 (CNN 2017). People across the globe find it hard to understand the justification of North Korea in detaining American citizens (Choe 2017; Surluga 2017; Grinberg 2017; Gorman 2017). Two of the most commonly used crimes used to justify detentions are crimes considered to be 'hostile acts' against the regime, or the illegal entry of an individual into the country. North Korea defines 'hostile acts' as actions intended to harm the regime or its image, 'hostile acts' are actions such as smear campaigns or removing regime propaganda without permission.

These two commonplace news categories project an image of North Korea as a country desperate to become a global contender. The survival of the regime has been in question since the 1990s, after the USSR dissolved; many believed North Korea would follow suit. In 1993, surveys of 25 multinational corporations operating in South Korea revealed an overwhelming majority of 18 corporations believed North Korea would collapse in the future. Two thirds of the 18 multinational corporations narrowed their prediction, believing the collapse would occur within the following three to five years (Business Asia, 1993). The world has watched North Korea with skepticism, especially during transitions of regime leadership. In 1994, the world watched intently as Kim Jung-il ascended to power following the death of 
his father, Kim Il Sung, the founding President of North Korea. Nations were doubtful of Kim Jung-il's capabilities as a leader, despite a decade of apprenticeship under his father. The world scrutinized North Korea again, in 2011, after the passing of Kim Jung Il led to the succession of his son, Kim Jung Un, at only 28 years old. North Korea has proven to survive each transition in leadership and continues to stun the world with the regime's resilience.

\section{PURPOSE AND METHODOLOGY OF THE RESEARCH}

The purpose of this research is to explore business aspects of North Korea that are different from the contemporary images mentioned in the previous section. It is the author's opinion that North Korea will be joining the global business community in the near future. Since the founding of North Korea in 1948 from the division of Korea in 1945, the utmost goal of the country has been Joache, a national policy to be a strong country without the intervention of foreign aggressors. Naturally, the geopolitical ties with communist China and Russia kept North Korea in minimal interaction with the West, particularly the United States. North Korea is currently the last and the most isolated communist country; all other communist countries have opened their doors to the global community over the past few decades. China in the 1970s opened up to the global community when leader Deng Xiaoping accepted the principles of market capitalism, followed by Russia in the 1990s by the dissolution of the USSR, then Vietnam in the 2000s followed the path toward the global economy, and finally Cuba in 2015 by resuming the diplomatic ties with the U.S. (Cote 2013, Liptak 2016).

As of today, North Korea has no official diplomatic ties with the U.S; Sweden serves as the protecting power for Australia, Canada, and the United States of America in North Korean territory (U.S. Department of State 2017). Few people know the truth about North Korea since the isolated state releases no information whatsoever to the outside world. There are, however, three sources on which North Korean watchers can rely: (1) expatriates of North Korea who sought asylum by defecting to South Korea while on foreign assignment, (2) refugees from North Korea that left the country via secret routes in China for a better life, and (3) foreign diplomats and journalists officially invited by the state, who had direct contact with North Korea citizens.

\section{FIVE REASONS FOR BUSINESS IN NORTH KOREA}

While North Korea has been painted by the barrage of criticism in the political news of the world as a cruel inhumane society and the poorest economy in the world, there is potential for North Korea in the future. Six reasons to project North Korea as a viable business partner are their (1) untapped underground resources, (2) economic geography favorable for effective supply chain via land routes, (3) affordable labor force with discipline and education, (4) the people's desire to achieve economic wellbeing, and (5) their latent needs of variety of consumer goods.

\section{(1) Untapped Underground Resources}

North Korea is rich in mineral resources and is exporting many of their resources to purchase import goods. The country is the world's second largest producer of magnesia (Sowinski 2000). The nation is blessed with underground resources, as evident by mining making up roughly 14 percent of the country's economy (Mollman 2017). The vast mineral reserves include iron, gold, magnesite, zinc, copper, limestone, molybdenum, graphite, and others----all told around 200 types of minerals. Also present are large amount of rare earth metals that are essential raw materials needed to make smartphones and many high-tech products. Among their resources at least 43 different mineral resources are considered to be highly valuable as overseas exports. A few of the significant raw materials are shown below in Table 1 with the reserve estimated by the various sources.

Among the many resources mentioned, the country's rare earth metals could be a valuable export for North Korea because of their value and relatively limited supply to the global community. Rare earth metals are used in the construction of everything from iPods to precision guided missiles. China supplies 
more than $95 \%$ of the world's output of rare earth metals; their control over the world's mineral supply has regional implications for Northeast Asia. For example, in 2010 Japan alleged that China suspended its export of minerals to Tokyo in response to a territorial dispute between the two countries. The EU, U.S., and Japan also recently brought a case against China at the WTO for unfairly inflating the prices of these minerals (Bruce 2012). Amidst these disputes, it is believed that North Korea may have as much as \$6 trillion dollars USD in rare earth elements. Overall, up to \$10 trillion dollars in USD worth of mineral resources could be buried in North Korean soil (Quartz 2017).

These estimates of minerals in North Korea are supported by private multinational corporations. SRE Minerals, a U.K. based equity firm, has a joint venture agreement with the Korea Natural Resources Trading Corporation for rights to develop rare earth deposits at Jongju in North Korea for the next 25 years with a condition to renew another 25 years (Els 2013). SRE Minerals announced North Korea may have two-thirds of the world's rare earth minerals in the quantity of 216 million tons (Keck 2014).

\section{TABLE 1}

\section{RAW MATERIAL RESERVES OF NORTH KOREA (IN BILLION TONS UNLESS OTHERWISE SPECIFIED)}

\begin{tabular}{|l|l|l|}
\hline \multicolumn{1}{|c|}{ Natural Resources } & Grade & North Korea's Reserve \\
\hline Lignite and Anthracite (million tons) & Coal grade & 4,500 \\
\hline Iron ore (million tons) & Fe 50\% & 5,000 \\
\hline Zinc (million tons) & & $4.0-4.5$ \\
\hline Lead ore (million tons) & & 3.0 \\
\hline Copper (million tons) & Metal & 2,900 \\
\hline Gold & Metal & 2,000 \\
\hline silver & & 5,000 \\
\hline Magnesite ore & MgO 45\% & 10 \\
\hline Hydro resources (m/kW) & & 10 \\
\hline Tidal energy (m/kW) & & 4.6 \\
\hline Tungsten (thousand tons) & WO3, 65\% & 246 \\
\hline Molybdenite (thousand tons) & MoS2, 90\% & 54 \\
\hline Nickel (thousand tons) & Metal & 36 \\
\hline Rare Earth (million tons) & & 6,000 (includes 216.2 REEs) \\
\hline
\end{tabular}

Sources: EIU Country Profile 1995-1996; Chon, Kim and Chun, 1995; Yang 2000; Korea Resource Cooperation 2009, xii.

\section{(2) Economic Geography as a Strategic Location}

There are two noteworthy elements of North Korea's economic geography: strategic location and topography. First, the strategic location of North Korea provides the neighboring countries with an excellent opportunity for regional and global economic development, if and when the land becomes accessible to others. Its proximity to emerging global economies, China and Russia, as well as advanced consumption societies, Japan and South Korea, offers a unique opportunity to contribute to global economic integration. As shown in the Figure 1, North Korea shares the longest border with China, making up $85 \%$ of North Korea's land line, $1 \%$ with Russia, and 14\% with South Korea. The country also has two seas: the East Sea (Sea of Japan) and the Yellow Sea in the west bound by two coastal lines that are essential for North Korea's expansion into the global commerce.

As of today, North Korea's location on the Korean peninsula has prevented South Koreans from shipping or receiving goods via land routes. South Koreans locked at the end of the peninsula were cut off geographically from the rest of the world. Above shown in Figure 2, the possible connection by a cross border railway between the South and North could become a modern day 'silk road.' Currently South Korea must ship and receive goods via air or by sea. It takes at least 30 days for a container shipment to reach Europe via their current routes. The aforementioned connection would reduce shipment time of goods and materials from South Korea to Europe by as much as 15 days. The hypothetical cross border railway could also reduce transportation charges for South Korea, saving the country money as well as 
time. The connection of any landline transportation would be advantageous to Russia, China, and multinational corporations operating in South Korea as well. Three possible railways could be easily connected if North Korea and South Korea were to come together. They are the Trans-Siberian Railway (TRS) through Russia, the Trans-Mongolian Railway, and the Trans-China Railway (TCR). All of these railways can originate from Pusan located at the southern tip of the country (Business Korea 2000).

\section{FIGURE 1 \\ MAP OF KOREAN PENINSULA}

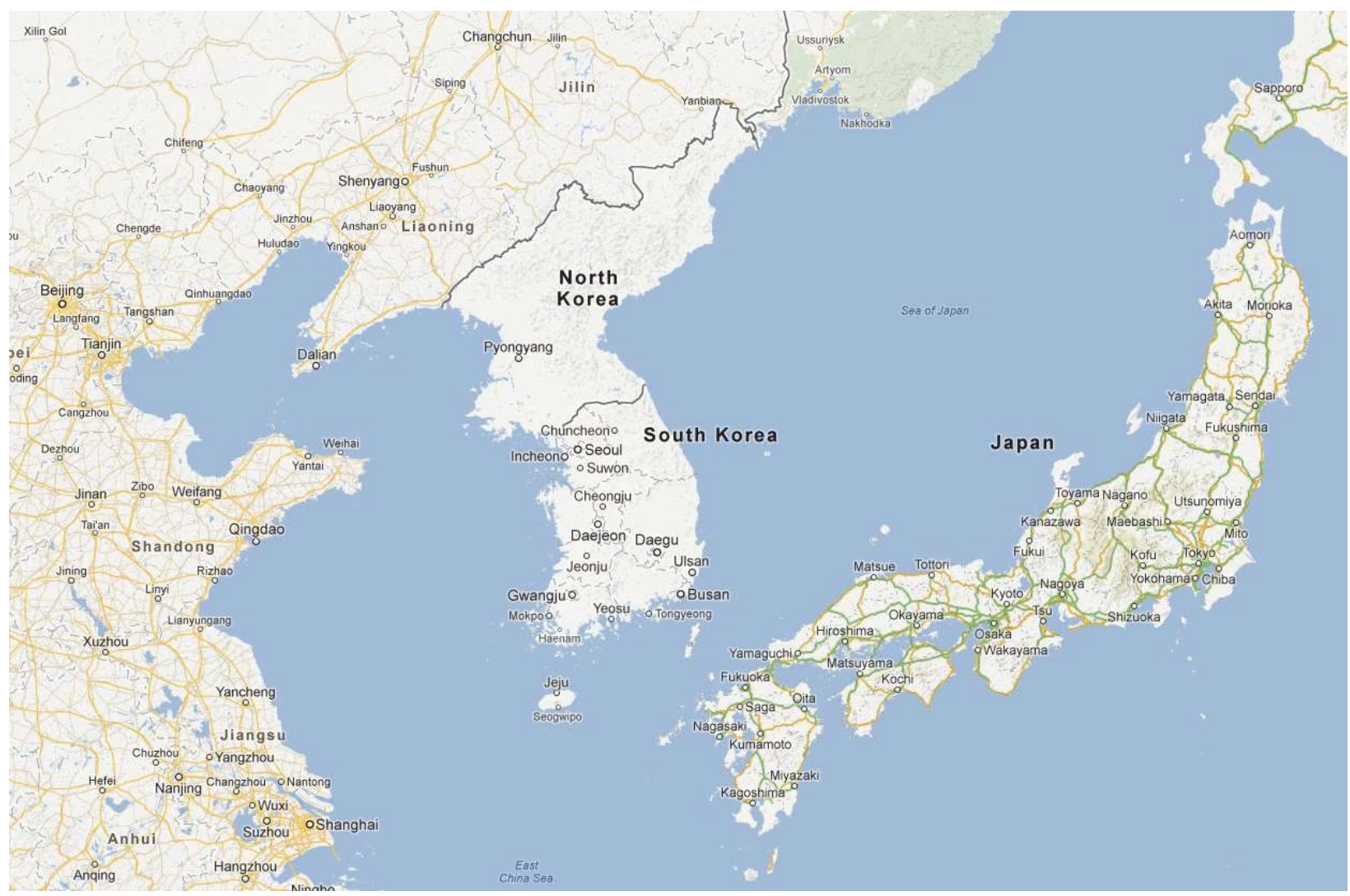

Source of the Map: hgsausageworks.bl

Business experts can predict that when the two Koreas connect these three railways, the Korean peninsula would emerge as the transportation hub of Northeast Asia. The land routes that start from Pusan and expand to Europe via North Korea, China, and Siberia are likely to replace the costly sea routes as the major artery for the transportation of goods. In short, this will provide a new opportunity for the Eurasian economy to expand; the railway connections would impact more than 2.5 billion people, producing onequarter of the world GNP.

Second, the topography of North and South Korea combined could create an effective synergy effect. The North and South are quite a contrast in terms of resource endowments, climate and many others except the same language and the identical race. The northern portion of the peninsula is too cold and too mountainous to be agriculturally significant, and therefore primary extractive industries and heavy secondary industries such as smelting iron and coal were developed; while warmer climate and greater availability of arable land relegated the south, favorable for food production and limited light industries (Lahood 2004). Even if the two Koreas were to combine, their size would be equitable to one state of the fifty states in the United States. 


\section{FIGURE 2 \\ MAP OF IRON SILK ROAD}

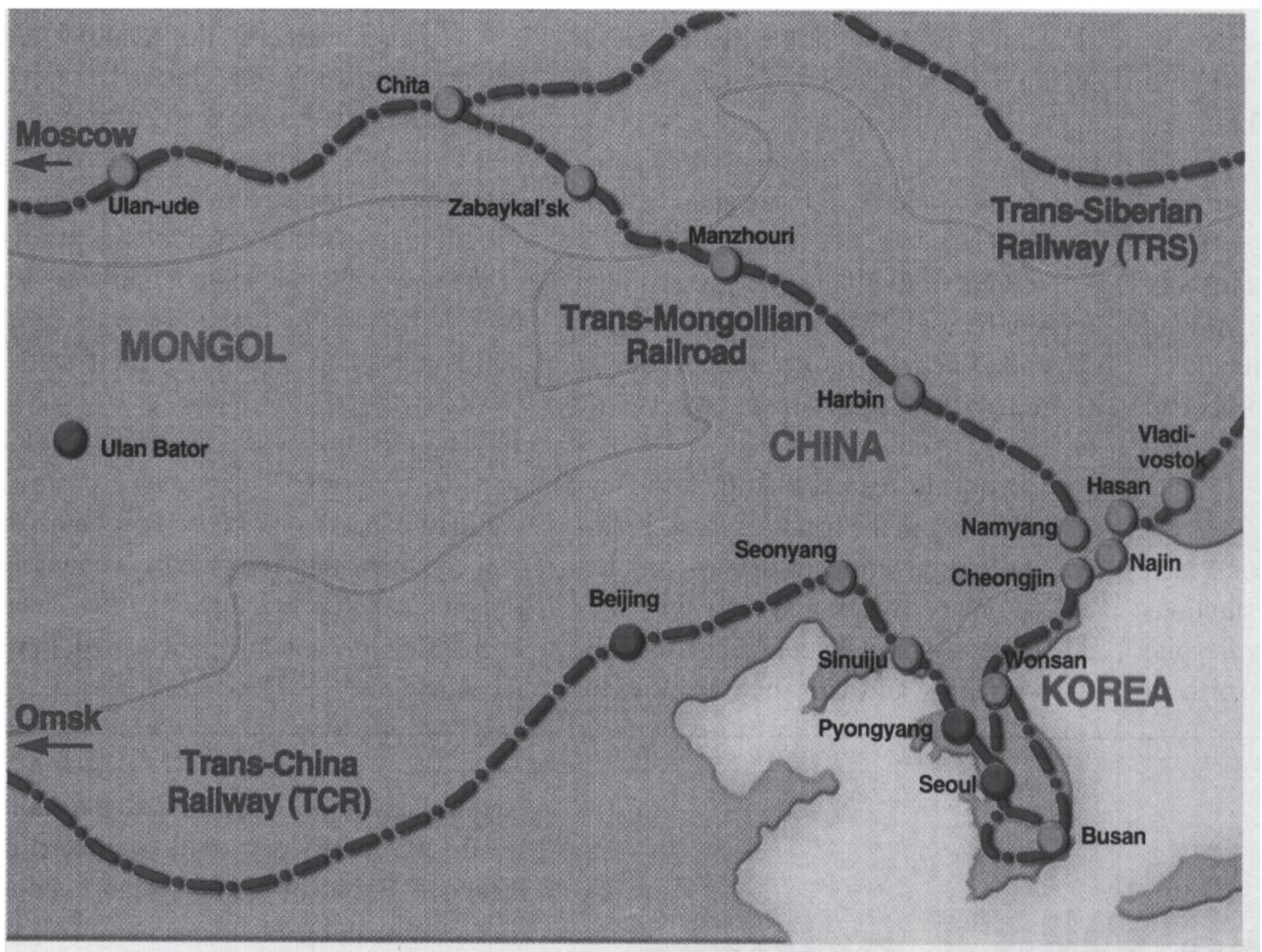

Source: Business Korea September 2000, p. 14.

\section{(3) Affordable Labor force with Discipline and Education}

North Korea's labor force consists of 14 million people (CIA World Factbook 2014). Unfortunately, abundance does not equate to effective productivity. The labor force grows idle as the country's economy stagnates with unemployment rates as high as $25.6 \%$ in 2013, estimated by the U.S. Department of State. Less than $20 \%$ of North Korea's factories are in operation and the country has experienced a declining economy throughout the years. The economy had a short-lived spurt in 1999 as a result of foreign aid and foreign direct investment after a decade-long decline. Currently, North Korea's economy is at a negative growth and ranked $213^{\text {th }}$ out of 230 countries in terms of GDP per capita.

The declining economy leaves a labor force eager to work for hard currency. The availability of an affordable labor force is appealing to South Korea and many multinational corporations. The attractive labor force situation of North Korea created the Kaesong Industrial Park in 2003 between both North and South Korea. Global firms can utilize contract manufacturing or direct investment in North Korea to maximize the utilization of their labor resources by redirecting high labor costs into other veins such as R\&D. North Korea can easily be an attractive low cost market to enter in order to avoid increasing labor costs in China.

Another strength accompanying the North Korean labor force is their literacy rate. According to the CIA World Factbook, the literacy rate of citizens aged 15 and over, is 100\% indicating that North 
Koreans have received thorough basic education that would help achieve desired efficiency in economic activities.

\section{(4) People's Desire to Achieve Economic Wellbeing}

The mindset of North Korean citizens can determine the future fate of the country. As of today, people in North Korea are deprived of most of the 30 basic human rights (United Nations 1948, Melody 2009), not to mention the five basic freedoms which include press, petition, religion, speech, and assembly; however, their desire to have a better life is indefatigable. Each year the number of North Koreans defecting to South Korea and the U.S. via China and other countries like Thailand in Southeast Asia, are increasing. The defecting citizens are hungry for work and are in the pursuit of freedoms they have been deprived in their own country.

The strong desire for improved economic lives by the North Koreans is easily manifested by the past achievements of their brothers and sisters in the South, who have elevated their own country to one of the nine advanced economies of the world with astounding success. The South Korean per capita GDP of $\$ 37,900$ has caught up with the third largest economy of the world, Japan's $\$ 38,900$ of last year (The World Factbook 2017). In South Korea, many workers avoid certain types of jobs called The Three Ds: Dirty, Dangerous, and Difficult. Jobs classified under the Three D's are mostly filled by foreign workers from Southeast Asia. North Koreans eager for work could easily fill any of these Three D's jobs.

\section{(5) Latent Needs of Variety of Consumer Goods}

Demands for goods and services are derived from the desires of consumers who have the ability to pay for them. As North Korea's government and labor force begin to receive rewards for their hard work, the country's overall ability and willingness to purchase domestic and foreign-made goods will undoubtedly increase. The purchasing power of people in North Korea is sure to rise in relation to the growing economic activities. The country can experience improved foreign relations with countries around the world and, in turn, reduce the tension of military relations and increase political stability; all of which would be influenced by their stepped up status in global commerce and business.

As of today, North Korea spends more than 30 percent of its GDP for national defense, compared to less than 3 percent spent by many other countries around the world, including South Korea (Lee 2000). The improved political stability of North Korea could result in diverting funds from their heavy defense budget to impoverished economic revitalization, in order to enhance the Chinese-style market-oriented business environment. The increase in personal incomes would become attractive to importers wishing to market their goods in the country of 24 million consumers.

\section{CONCLUSION AND RECOMMENDATION}

As Robert Service states in his book, Comrades! A History of World Communism, the country that adheres most strictly to communist principles is North Korea, among the five remaining communist countries on the earth (Service 2007). The vertically hierarchical society with collective culture has been experiencing economic difficulty with near-starvation in some parts of the country. Putting aside the dire political issues such as the nuclear arms program, the country presents several positive facts attractive to many multinational corporations for global businesses.

For businesses, the country is easily accessible by water on the east and west coasts, and by land connecting to the large markets; China and Europe, once the region was stabilized, and by short distance from Japan, the third largest economy in the world. South Korea's advanced technology and established business infrastructures are highly valuable backdrops for entering the North Korean markets. A welleducated labor force with $100 \%$ literacy rate in reading and writing is another significant factor for business efficiency among the several positive characteristics discussed.

North Korea is easily accessible by water and by land; the country is primed to enter large markets such as with China, Europe, and Japan. South Korea's advanced technology and established business infrastructures are highly valuable backdrops for entering the North Korean market as well. North Korea 
offers a well-educated labor force with a $100 \%$ literacy rate, which is a significant factor for business efficiency. The country is also well endowed with natural resources that would benefit the global market and ease China's control over the world's mineral supply. North Korea has the potential to be a successful contributor to the global community, and their participation would result in benefits to their own economy and standard of living.

\section{REFERENCES}

Bruce, Scott Thomas (2012), North Korea's Six Trillion Dollar Question, The Diplomat, August 30. Business Asia (1993), "Before the North Korean Flood," October 25, Vol. 25, No. 22.

Business Korea (2000), "Iron Silk Road: Rail Across DMZ spans two continents," September, pp. 13-15.

Choe, Sang-Hun (2017), "North Korea Accuses U.S. of 'Mugging' Its Diplomats in New York," The New York Times, June 19.

Choi, Kyung-soo (2011), "The Mining Industry of North Korea," Nautilus Institute for Security \& Sustainability, August 4.

Chun, H.S., Y.W. Kim, W. Chun (1995), North Korean Economy, pp. 338-339. Seoul, Shin Young Sa. CNN (2017), "Why does North Korea detain Americans, and what does it takes to get them out?" June 15.

Cote, Rob (2013), "The Five Remaining Communist Countries," The Richest, December 7.

EIU Country Profile 1995-1996 (1996), The Economist Intelligence Unit Limited, p. 76.

Els, Frik (2013), Largest Known Rare Earth Deposit Discovered in North Korea," InfoMine, December 5.

Finnegan, Conor 2017), "What you need to know about the 3 Americans still detained in North Korea," ABC News, June 20.

Gorman, Steve (2017), "U.S. Student who returned from North Korea in coma has died," June 19, MSNBC.

Grinberg, Emanuella (2017), "Former North Korea detainee Otto Warmbier dies," CNN, June 19.

Keck, Zachary (2014), "North Korea May Have Two-Thirds of World's Rare Earths, The Diplomat, January 22.

Korea Resource Cooperation (2009), Current Development Situation of Mineral Resources in North Korea, p. xii.

Lahood, Albert A. (2004), Economic Geography in North Korea by Eugene J. Palka and Francis A. Galgano, p. 89.

Lee, D.H. (2000), "25 Percent Reduction of Military Expenditure Could Build a Kyung-Pu Highway Each Year," Joong Ang Daily, November 20, p. 4.

Liptak, Kevin (2016), "Obama Arrives in Cuba; hopes visit will usher in change," CNN, March 21.

Melody, Sarah (2009), "We have 30 Basic human Rights: Do You Know Them?" November 16 at http://www.samaritanmag.com/we-have-30-basic-human-rights-do-you-know-them

Mollman, Steve (2017), "North Korea is sitting on Trillion of Dollars of Untapped Wealth, and Its Neighbors Want In," Quartz, June 16.

Quartz (2017), "North Korea has up to \$10 Trillion of Mineral Worth," June 19.

Service Robert (2007), Comrades! A History of World Communism, McMilliam.

Sowinski, L.L. (2000), "Uncovering Market Opportunities in Asia," World Trade, pp. 34-41.

Svrluga, Susan (2017), "Otto Warmbier dies days after release from North Korean detainment," The Washington Post, June 19.

United Nations (1948), Universal Declaration of Human Rights, Paris, France, December 10.

U.S. Department of State (2017), North Korea (DPRK) at https://www.state.gov/index.htm.

Yang, S. (2000), Magnesite and Iron Ore: 43 Valuable Natural Resources, Joong Ang Ilbo Daily, p. 34. 